\title{
Scenariusz filmowy jako inspiracja
}

Czym jest scenariusz filmowy? Jak powstaje? Co odróżnia dobry scenariusz od złego? Co stanowi jego wartość?

$\mathrm{Na}$ co dzień nie zastanawiamy się specjalnie nad fenomenem twórczości scenariopisarskiej. Refleksję nad scenariuszem zdominowała traktowana w podręcznikach i opracowaniach w sposób instruktażowo-użytkowy technika jego pisania. Takie utylitarne podejście mocno ogranicza perspektywę rozumienia pracy nad tworzeniem scenariusza. Mimowiednie traci ono bowiem z pola widzenia to, co w niej najistotniejsze: w konsekwencji przesłaniając i zastępując samą twórczość. Wszystko, co do niej należy, wydaje się mniej lub bardziej oczywiste. Brakuje ciągle pogłębionej naukowej refleksji nie nad coraz nowymi zmieniającymi się technikami pisarskimi, lecz nad teorią praktyki pisania scenariuszy.

Praktyka pozbawiona teorii (resp. wnikliwej refleksji nad - nie całkiem uświadamianą nawet przez samych scenarzystów - złożonością procesu twórczego, z jakim mamy do czynienia w tej dziedzinie) staje się czymś rutynowym, prowadząc w najlepszym razie do powstawania rzeczy wtórnych: replik, standardów, „sprawdzonych” formatów, wielokrotnie używanych matryc kina i wzorców widowiska filmowego. Zamiast oryginalnej formy twórczości, jaką jest twórczość scenariuszowa, mamy przeważnie do czynienia z jej postacią zastępczą, w której liczy się nade wszystko „co” (poruszony temat) kosztem „jak” (odtwórcza forma).

To właśnie kłopotliwy przypadek dzisiejszego rodzimego scenariopisarstwa, w którym nielicznych zawodowych scenarzystów coraz bardziej wypierają i zastępują liczni piszący dla siebie samych reżyserzy.

Propozycja badawcza zawarta w poniższym artykule odchodzi daleko od utartych ścieżek i dróg refleksji nad problematyką scenariusza i scenariopisarstwa. W centrum naukowej refleksji znalazł się w nim nie uniwersalny wzorzec i recepta na to, jak napisać doskonały scenariusz, lecz unikatowy program rozwojowy łączący w sobie trzy aspekty:

1) potencjał projektowy scenariusza

2) nieokreśloność i otwartość jego formy

3) aksjologię scenariusza.

W dalszej części rozważań spróbujemy kolejno przedstawić i skomentować wskazane wyżej aspekty scenariusza filmowego w kontekście teorii praktyki jego tworzenia oraz profesjonalnej oceny. 
Scenariusz jako projekt filmu
Pomysł na film można przedstawić metaforycznie jako jego zalążek. Pomysł nie jest jeszcze w żaden sposób scenariuszem. Aby mógł się nim stać, potrzebna jest struktura, forma, zarys mającej powstać całości wyrażony w słowach bądź - co bywa nieporównanie rzadsze poza sztuką animacji - w rysunkach, w postaci tak zwanego scenorysu. W momencie, kiedy pomysł zaczyna przybierać kształt scenariusza (w którejkolwiek z wielu możliwych jego odmian), rozpoczyna się długi proces jego ciągłego kształtowania i krystalizacji. Gotowe dzieło filmowe wyraża określoną ideę, scenariusz zaś jest owej idei początkiem i pierwszym - zapisanym w słowach bądź narysowanym - wyrazem.

W profesjonalnie zorganizowanej kinematografii scenariusz obligatoryjnie pełni pierwszorzędnie ważną rolę. Po pierwsze, inicjuje proces twórczy wokół przyszłego filmu. Po drugie, pozwala w sposób relatywnie niekosztowny dla producenta rozwijać i doskonalić projekt powstającego dzieła: nie w toku realizacji zdjęć, gdy jest już na to za późno, lecz w fazie przedzdjęciowej, gdy wszystko można jeszcze stosunkowo prosto zmienić. Po trzecie, stanowi rodzaj fali nośnej, która dostarcza energii twórczej, już w stadium preprodukcji wywołując i uruchamiając ciąg wielokierunkowych i wieloosobowych działań poszczególnych współtwórców powstającego dzieła.

W źle funkcjonującym przemyśle filmowym scenariusz jest czymś mało istotnym. Schodzi wówczas na margines tego, co uchodzi za prawdziwie ważne. Staje się w takich przypadkach rodzajem sztucznej atrapy, którą wytwarza się i sporządza tylko raz, aby pełniła funkcję „podkładki” dla dalszych etapów realizacji. Liczy się wtedy tylko jako dokument o znaczeniu decyzyjno-admnistracyjnym, a nie w kontekście twórczym, z myślą o którym powstawał. Tak traktowany scenariusz traci w punkcie wyjścia swój kreatywny potencjał, nie odgrywając w dalszych etapach realizacji projektu roli, do której został powołany.

Potencjał projektowy scenariusza filmowego, o którym mowa, może być bardzo różny: od tworu skończenie banalnego w swym wyrazie, do oryginalnego projektu o niezwykłym stopniu nośności. Jedno pozostaje w tym względzie wspólne: za każdym razem potencjał ten wynika nie z jego specjalnych literackich walorów, lecz z wielorako inspirującej funkcji zapisu wizji, jaka przypada mu w udziale.

Pierwszym zainspirowanym - poza samym autorem scenariusza oczywiście - jest zwykle producent. To jemu przypada rola promotora projektu i przywilej osoby podejmującej decyzję o jego dalszych losach. W ślad za tym idą kolejne decyzje stopniowo, krok po kroku, zmierzające do realizacji. Bez udziału scenariusza trudno sobie $\mathrm{w}$ jakimkolwiek profesjonalnie funkcjonującym przemyśle filmowym wyobrazić nie tylko pozyskanie środków finansowych na realizację, ale także odpowiedzialny, osobisty akces poszczególnych współtwórców przyszłego dzieła: reżysera, aktorów, autora zdjęć, scenografa i in. 
Scenariusz jako projekt filmowy otwiera drogę do dalszych etapów procesu twórczego. W tym sensie od ponad stu lat jest on w świecie kinematografii niezastąpionym pomostem łączącym początkową ideę z tym, co doprowadza do realizacji projektu i powstania filmu.

Lektura scenariuszy klasycznych dzieł filmowych bywa zajęciem ze wszech miar pouczającym. Okazuje się podczas niej, że film, który znamy, za każdym razem zdaje się nie pasować do swego pierwotnego opisu. Intrygująca odmienność. Dla samych filmowców - jeśli nie przemyśleli oni głębiej fenomenu procesu twórczego w sztuce, jaką się zajmują - owa widoczna różnica między jednym a drugim staje się (pseudo)argumentem na rzecz tezy, iż w ogóle scenariusz nie jest reżyserowi i jego współpracownikom do niczego potrzebny. Zbędność owa - argumentują - wynika przede wszystkim z oczywistej różnicy użytych tworzyw (słowa versus ruchome obrazy), a także stąd, iż scenarzysta nie wytwarza filmu jako takiego, z czym wypada się zgodzić.

Struktura dzieła otwartego, jakim jest dobrze wymyślony scenariusz, zawiera w sobie „hipotezę nieokreśloności”, by posłużyć się celnym określeniem Umberta Eco[1]. Jest ona jako wynik aktu twórczego - pierwszym ogarnięciem bezładu i entropii nieistniejącego jeszcze dzieła filmowego. To scenarzyście przypada owa zaszczytna, ale też niezmiernie trudna, rola jego akuszera.

Nieokreśloność scenariusza filmowego rozpatrywana w kategoriach semiotycznych zawiera w sobie, używając terminologii Romana Ingardena, „miejsca niedookreślenia”. W zależności od ich charakteru mogą one stanowić zarówno wadę (miejsca puste, partie niedopracowane, niedoróbki i niedomyślenia), jak i zaletę scenariusza, stanowiąc rodzaj terytorium wyobraźni do wypełnienia. Sercem scenariusza jest jego rozumne wewnętrzne spojrzenie, emanujące $\mathrm{z}$ zawartej w nim wizji człowieka i świata.

Dobry scenariusz okazuje się tworem paradoksalnym. Z jednej strony, w swym właściwym, a więc w pełni rozwiniętym, kształcie zawiera wszystko, co niezbędne do wykreowania przyszłego filmu. $\mathrm{Z}$ drugiej, przeciwnie - pełno w nim miejsc niedookreślenia, przestrzeni, które zostaną dopiero wypełnione przez innych współtwórców. Z tego właśnie powodu sprawą tak ważną staje się wnikliwa i krytyczna lektura scenariusza. W kategoriach biznesowych jej głębszy sens można by określić jako due diligence, czyli audyt przed dokonaniem transakcji, mający na celu optymalnie ograniczyć ryzyko i podnieść jej bezpieczeństwo.

Naturalnie pierwszym krytykiem bywa w procesie ciągłej autokorekty sam scenarzysta. Jako autor jest (a w każdym razie powinien być) sceptycznym wizjonerem. Tworzy bowiem wizję czegoś

[1] U. Eco, Dzieło otwarte. Forma i nieokreśloność w poetykach współczesnych, tłum. J. Gałuszka, Czytelnik, Warszawa 1973, s. 7.

\section{Nieokreśloność i otwartość formy}


nieistniejącego, posługując się przy tym krytycznym rozumowaniem i zdolnością przewidywania filmowych konsekwencji takich a nie innych własnych decyzji. Jeśli jest autorem wytrawnym, dysponującym osobistym empirycznym doświadczeniem, popełnia w trakcie pisania mniej błędów niż scenarzysta debiutant. Nie znaczy to jednak, że dzieło scenariuszowe jego autorstwa jest czymś więcej niż strukturą w procesie przemiany w inną strukturę.

Nie ma scenariuszy doskonałych, definitywnie zamkniętych w swym kształcie. Bywają scenariusze optymalnie dopracowane, których podstawową zaletą nie jest zamkniętość, lecz przeciwnie - umiejętnie zaprojektowana przez scenarzystę - otwartość ich ukształtowania. Tego pożądanego w twórczości i sztuce filmowej efektu nie dadzą żadne "sprawdzone" szablony, matryce dramaturgiczne czy gotowe wzorce układów fabularnych. Scenariusz jest strukturą partycypacyjną. Jej charakterystyczną właściwość stanowi - umiejętnie zaprojektowany przez scenarzystę z myślą o innych twórcach filmu i rzecz jasna o wi$\mathrm{dzu}$ - polifoniczny układ całości rozpostarty na siatce wzajemnych i różnopoziomowych powiązań między poszczególnymi elementami.

Aksjologia
scenariusza

[2] W. Goldman, Przygody scenarzysty, przeł.

M. Karpiński, Wydawnictwa Artystyczne i Filmowe,

Warszawa 2006, cyt. s. 222. dzająco prosta.
Praca scenarzysty polega na wielokrotnie ponawianym twórczym wymyślaniu. Pisząc scenariusz filmowy, wymyśla się opowieść w hipotetycznej formie ruchomych obrazów: jej bohaterów, postaci drugoplanowe i epizodyczne, czas i miejsca akcji, bieg zdarzeń, sceny, obrazy, poszczególne epizody, sytuacje ekranowe, konflikty, interakcje zachodzące między postaciami, gesty i zachowania, scenerie, rekwizyty, kostiumy etc. Wraz z tym projektuje się także konstrukcję opowieści, sposób narracji, styl i kompozycję całości.

Droga prowadząca scenarzystę do tego celu okazuje się zawsty-

Pisanie - powiada wybitny reprezentant tego zawodu William Goldman sprowadza się w gruncie rzeczy do jednego: do zamknięcia się w pokoju i zabrania się do tego. Zapełniania papieru w taki sposób, w jaki jeszcze nikt nigdy tego nie zrobił. I chociaż w takiej chwili fizycznie jesteś sam, ale demon nie przestaje cię nawiedzać i nigdy cię nie opuszcza, ten demon świadomości swoich własnych straszliwych ograniczeń, beznadziejnej nieumiejętności, niemożliwości zrobienia tego kiedykolwiek dobrze. Niezależnie od tego, jak brylantowo błyszczą pomysły tańczące w twojej głowie, na papierze stają się przyziemne i ciężkie[2].

Wymyślanie jest nieredukowalnym sensem i istotą wysiłku scenarzystki/scenarzysty/scenarzystów, w którym nikt i nic nie może jej/ jego/ich zastąpić. To kreatywne zadanie i ciężka, żmudna praca. O jej ocenie decyduje wiele różnych kryteriów. Jeśli podstawowe kryterium oceny scenariusza stanowi wyłącznie okazjonalna atrakcyjność, publicystyczna wymowa bądź szeroko pojęta „użyteczność” poruszanego 
$\mathrm{w}$ nim tematu, to istnieje graniczące $\mathrm{z}$ pewnością prawdopodobieństwo, że tak zorientowany projekt scenariuszowy zamieni się w konsekwencji w filmową katastrofę.

Dobrze pomyślany i skonstruowany scenariusz staje się tekstem wielogłosowym. Podstawową właściwością takiego tekstu jest dyskursywna interferencja poszczególnych jego elementów, zachodząca zarówno wewnątrz, jak i na zewnątrz przekazu. To właśnie ona - owa przemyślnie skonstruowana, pełna nośnych rozwiązań i zaskakujących niespodzianek profilmowa dyskursywność - stanowi pierwszorzędną zaletę scenariusza i podstawowe kryterium jego oceny.

Dobry scenariusz, nie mówiąc już o scenariuszach wyśmienitych w swej warsztatowej doskonałości, okazuje się tekstem wysoko zorganizowanym. Jako taki realizuje wiele zadań i pełni wiele różnych funkcji. W szystkie one - i to jest ich wartość stricte użytkowa - odkrywają nieustannie swoją służebność, koncentrując się wokół charakteru mającego dopiero powstać filmu.

Ocena, jakiej podlega każdy scenariusz, rzadko ma charakter jednokrotny. Między będącym punktem wyjścia pomysłem na film nieważne w tym momencie, jak bardzo był on olśniewający i jak wyraziście się rysował - a ostateczną wersją ekranową istnieje długa seria stadiów przemiany: przekierunkowań, korekt, zmian, rewizji etc. W praktyce pracy nad scenariuszem zmiany te przeprowadzane są wiele razy i pod różnym kątem. Wraz z nimi zmieniają się także kryteria oceny. To rzecz naturalna i zrozumiała, niczym crash test pojazdu, który umożliwia producentowi wypracowanie optymalnie bezpiecznej jego konstrukcji, chroniącej przez skutkami wypadku.

Pierwszym oceniającym scenariusz filmowy staje się zazwyczaj właśnie producent. Zarówno w przypadku, gdy sam zleca autorowi jego opracowanie i napisanie, jak i wówczas, gdy przyjmuje do realizacji bądź też odrzuca propozycję scenariuszową, która do niego trafiła.

W warunkach profesjonalnie zorganizowanej kinematografii, takiej jak nasza, scenariusz bywa recenzowany i oceniany wiele razy. Źle, jeśli podstawowym (lub jedynym) kryterium oceny staje się wartość literacka tekstu. Dobrze, jeżeli eksperci i komisje kwalifikujące projekt do dalszych etapów dostrzegają w scenariuszu jego profilmowe wartości. Znakomicie, jeśli towarzyszy temu wnikliwa ocena merytoryczna wytrawnego eksperta. Ocena, która z reguły zawiera sui generis korektę cudzej wizji zaprezentowanej w scenariuszu, polegającą na precyzyjnym wskazaniu zalet i słabości recenzowanego projektu scenariuszowego.

Powstaje wtedy szansa na odpowiednie skorygowanie wad i niedoskonałości. Uwaga: ani ekspert recenzujący przedłożony do oceny scenariusz, ani konsultant scenariuszowy proszony o wskazanie jego zalet i słabości nie są osobami, do których należy dokonanie koniecznych zmian. Tym bardziej nie powinna tego czynić instytucja oceniająca projekt. Zadanie to należy pozostawić w gestii producenta filmu. Na jego życzenie zmiany może wprowadzić sam autor scenariusza lub też - jeśli nie potrafi ich dokonać - wytrawny lekarz scenariuszy (script doctor). 
Dla aksjologii scenariusza filmowego ważne jest przekonanie o tym, że zdarzają się scenariusze ewidentnie złe, ale nie ma scenariuszy skończenie doskonałych, a praca nad ich kształtem $z$ natury rzeczy musi mieć charakter permanentny tak długo, aż rozpoczną się zdjęcia, a częstokroć również o wiele dłużej, gdy w fazie pozdjęciowej, w trakcie montażu filmu, poszukujemy dla niego optymalnie nośnych rozwiązań artystycznych.

Konkluzja
Ostateczna konkluzja niniejszych rozważań przedstawia się następująco. Scenariusz filmowy bywa dziełem inspiracji w trzech co najmniej komplementarnych względem siebie znaczeniach.

Po pierwsze, stanowi on mniej lub bardziej oryginalny w swym kształcie projekt wyobraźni wykreowany przez jednego lub wielu autorów, zawdzięczający im pierwotną, skonkretyzowaną w słowie (bądź jak w przypadku scenorysu - w formie rysunkowej), wizję przyszłego dzieła. Jest wówczas niejako wstępną wizją projektową - wytworzoną w określonym kształcie tekstowym - jako podstawa inspiracji służącej $\mathrm{w}$ fazie preprodukcji do dalszego rozwoju projektu. Obojętne w tym momencie, czy chodzi o film fikcji, dokument, film animowany czy też film eksperymentalny, obarczony bardzo wysokim współczynnikiem nieprzewidywalności zamierzonego efektu.

Po drugie, scenariusz filmowy - mimo iż w fazie finalnej swego powstawania przybiera postać w określony sposób skonkretyzowaną nie jest strukturą definitywną, lecz otwartą. W procesie rewritingu otwiera się on na nowo, rozpościera, żyje i powstaje wielokrotnie. Jako struktura w rozwoju z każdą kolejną wersją dostarcza nowych inspiracji autorowi bądź autorom wersji następnych. Dzieje się tak już na etapie przejścia od pomysłu do pierwszej, szkicowej jeszcze, postaci scenariusza. A potem nieustannie, gdy powstają: nowela filmowa, treatment, kolejne drafty i wreszcie scenariusz właściwy.

Sztuka pracy ze scenariuszem i nad scenariuszem polega na umiejętnym wydobywaniu i rafinacji tego, co w nim cenne, przy jednoczesnym pozbywaniu się rzeczy nietrafionych i odrzucaniu zbędnych.

I po trzecie, w swym kształcie rozwiniętym, zaakceptowanym ostatecznie przez producenta i reżysera, scenariusz nadal podlega kolejnym metamorfozom. Scenariuszowy zapis projektu utworu filmowego staje się w tym momencie podstawą scenopisu zdjęciowego. W dalszych zaś fazach realizacji pełni funkcję inspiratora i katalizatora synergii twórczej zachodzącej - najczęściej już bez osobistego udziału scenarzysty - pomiędzy jego współtwórcami. To oni (kreatywny producent i jego równie kreatywni współpracownicy: reżyser, twórca zdjęć, scenograf, kostiumolog, kompozytor, aktorzy i inni) czerpią odtąd dla siebie inspirację z kart scenariusza z myślą o optymalnym efekcie ekranowym, który został w nim wcześniej opisany i zaprojektowany.

Wynika stąd, iż nie tylko sam scenariusz (nowela filmowa, treatment, kolejne wersje, scenariusz właściwy, scenorys, scenopis zdjęciowy), ale także dzieło filmowe powstaje w procesie twórczym 
wielokrotnie. Tam wszędzie, gdzie mamy do czynienia z profesjonalnie uprawianym kinem artystycznym, proces owej re-wizji, ciągłego przetwarzania i stale na nowo podejmowanego remodelingu stanowi zarówno w przeszłości, jak i współcześnie - pierwszorzędnie ważny aspekt tej dziedziny twórczości i sztuki.

\section{Literatura}

Umberto Eco, Dzieło otwarte. Forma i nieokreśloność w poetykach współczesnych, przeł. Jadwiga Gałuszka, Lesław Eustachiewicz, Alina Kreisberg i Michał Oleksiuk, Czytelnik, Warszawa 1973 i wydania nast.

Janusz Głowacki, Przyszłem, czyli jak pisałem scenariusz o Lechu Wałęsie dla Andrzeja Wajdy, Świat Książki, Warszawa 2013

William Goldman, Przygody scenarzysty, przeł. Maciej Karpiński, Instytucja Filmowa Agencja Scenariuszowa, Warszawa 1999

Marek Hendrykowski, Scenariusz filmowy i jego odmiany. Studium przedmiotu, „Images” vol. 9, no. 20, 2012

Maryla Hopfinger, Literatura i media po 1989 roku, Oficyna Naukowa, Warszawa 2010

Maciej Karpiński, Niedoskonate odbicie. Warsztat scenarzysty filmowego, Wydawnictwa Artystyczne i Filmowe, Warszawa 2006

Bruno Latour, Splatajac na nowo to, co spoteczne. Wprowadzenie do teorii aktora-sieci, przeł. Aleksandra Derra, Krzysztof Abriszewski, Universitas, Kraków 2010

Robert McKee, Substance, Structure, Style and the Principles of Screenwriting, HarperCollins Publishers, New York 1997

Ryszard Nycz, Poetyka doświadczenia. Teoria - nowoczesność - literatura, Wydawnictwo IBL PAN, Warszawa 2012

Oliver Schütte, Praca nad scenariuszem, przeł. Maria Borzęcka, Aneta Głowska, Wydawnictwo Naukowe PWN, Warszawa 2005

Anna Wróblewska, Adaptacje pod znakiem zapytania, „Biuletyn Filmowy SFP” 2010, nr 2 